http://dx.doi.org/10.11646/zootaxa.3790.4.1

http://zoobank.org/urn:Isid:zoobank.org:pub:B7904CA0-5A01-43FF-BBA6-6B9F15B3FEAD

\title{
The genus Exogone (Polychaeta: Syllidae) from the Brazilian coast, with the description of a new species
}

\author{
KARLA PARESQUE ${ }^{1 *}$, MARCELO VERONESI FUKUDA ${ }^{1} \&$ JOÃO MIGUEL DE MATOS NOGUEIRA ${ }^{1}$ \\ ${ }^{1}$ Laboratório de Poliquetologia (LaPol), Departamento de Zoologia, Instituto de Biociências, Universidade de São Paulo, R. do \\ Matão, travessa 14, n. 101, 05508-090, São Paulo, SP, Brazil \\ *corresponding author: kparesque@gmail.com
}

\begin{abstract}
A new species of Exogone, E. gigas sp. n., is described herein, together with E. africana, E. arenosa, E. dispar, E. naidinoides, E. rolani, and E. simplex, collected along the Brazilian coast, including new morphological details. The distribution of E. breviantennata is expanded to include the states of Espírito Santo, Paraíba and Pernambuco. Exogone gigas sp. n. is characterized by having a large median antenna, the absence of dorsal cirri on chaetiger 2, and having a triangular process and minute spines on the shaft of the spiniger-like chaetae on chaetiger 2 . The Brazilian specimens are compared to the morphologically most similar congeners. A key for the species described in this paper is provided.
\end{abstract}

Key words: Exogoninae, new occurrence, taxonomy, Atlantic Ocean, phytal.

\section{Introduction}

Syllidae Grube, 1850 is one of the largest families of polychaetes, currently comprising around 700 species, with more than 70 genera (Aguado et al. 2007). The state of knowledge of the syllid fauna occurring off the Brazilian coast is still poor, considering the great extension of the coast and the diversity of syllids in areas that have been more thoroughly studied (San Martín 2003, 2005; San Martín \& López 2003; San Martín \& Hutchings 2006; San Martín et al. 2008a, 2008b, 2010). Up to the present, about 140 species have been recorded from Brazil (Rullier \& Amoureux 1979; Morgado \& Amaral 1985; Nogueira 2000, 2006; Nogueira et al. 2001, 2004; Nygren \& Gidholm 2001; Nogueira \& San Martín 2002; Fukuda \& Nogueira 2006, 2013a, b; Paiva et al. 2007; Nogueira \& Fukuda 2008; Nogueira \& Yunda-Guarín 2008; Fukuda et al. 2009, 2012, 2013; Fukuda 2010; Berlandi et al. 2011; Amaral et al. 2012; Paresque \& Nogueira 2014).

Exogone Ørsted, 1845 is a cosmopolitan genus commonly found in samples collected off the Brazilian coast (Nogueira 2000; Nogueira et al. 2004; Berlandi et al. 2011). However, only eight species of this genus have been recorded from Brazil: E. aquadulcensis Pascual, Núñez \& San Martín, 1996, E. arenosa Perkins, 1981, E. breviantennata Hartmann-Schröder, 1959, E. dispar Webster, 1879, E. lourei Berkeley \& Berkeley, 1938, E. marisae Pascual, Núñez \& San Martín, 1996, E. naidina Ørsted, 1845 and E. verugera (Claparède, 1868) (see Amaral et al. 2012). A formal description of Brazilian populations was provided only for E. breviantennata (Nogueira et al. 2004), with the remaining records coming from identifications for ecological studies or unpublished theses and dissertations, and frequently without voucher specimens available for examination. Therefore, only E. breviantennata and the species dealt with in this paper can be confirmed as occuring in Brazilian waters. Brazilian specimens of Exogone africana, E. arenosa, E. dispar, E. gigas sp. n., E. naidinoides, E. rolani, and $E$. simplex from recent collections are described and illustrated herein. 
Exogone longicornis also has dorsal cirri on chaetiger 2 and a triangular process is present on the shafts of spiniger-like chaetae of chaetigers 1 and 2 (San Martín 2005). In addition, E. longicornis has shorter blades of spiniger-like chaetae throughout, $26 \mu \mathrm{m}, 26 \mu \mathrm{m}$, and $20 \mu \mathrm{m}$ long on anterior, midbody and posterior chaetigers, respectively, and a proventricle with 33-38 rows of muscle cells. In contrast, E. gigas $\mathbf{s p .} \mathbf{n}$. has blades of spinigerlike chaetae $30-50 \mu \mathrm{m}, 22-45 \mu \mathrm{m}$, and $17-35 \mu \mathrm{m}$ long on anterior, midbody and posterior chaetigers, and a proventricle with $25-27$ rows of muscle-cells.

Exogone multisetosa is a smaller species, the holotype, with 41 chaetigers, was described from the Pacific Ocean (Lima, Peru) and can be differentiated from E. gigas sp. n. by having a shorter, squared triangular process on spiniger-like chaetae of chaetiger 2 , ventral simple chaetae with acute tip, and shorter proventricle, through 2.5-3 segments. Exogone arenosa differs from E. gigas sp. n. by having dorsal cirri on chaetiger 2, pharynx through 7 segments, and proventricle with $27-36$ rows of muscle cells.

Etymology. The epithet gigas is derived from Latin, meaning "giant", and refers to the length of this species, which is the longest known for this genus.

Distribution. Atlantic Ocean: Brazil (Rio de Janeiro and São Paulo). From the intertidal zone to ca. $143 \mathrm{~m}$.

\section{Acknowledgements}

We are thankful to Petrobras, namely Ana Paula Falcão (CENPES/PETROBRAS) and Prof. Dr Helena Lavrado (Universidade Federal do Rio de Janeiro), of the 'Habitats' Project. The Project 'Diversity of Polychaeta (Annelida) on sandstone reefs off northeastern Brazil, states of Paraíba and Pernambuco' was funded by the Conselho Nacional de Desenvolvimento Cientifico e Tecnológico - CNPq (proc. 481510/2008-7) and by Fundação de Amparo a Pesquisa do Estado de São Paulo - FAPESP (proc. 2010/52116-4). In addition, KP receives a Ph. D. fellowship from FAPESP (proc. 2009/17606-3) and MVF receives a post-doc fellowship from FAPESP (proc. 2010/ 19424-7). We are also thankful to Orlemir Carrerette, Rudá Amorin, Rafael Brito, Carmem Alonso Samiguel, and all students of Laboratório de Invertebrados Paulo Young (Universidade Federal da Paraíba - UFPB) for the help with the collections; to Enio Mattos and Phillip Lenktaitis for preparing the specimens and photographing them under the SEM; to the team of 'BIOTA', 'REVIZEE', and 'HABITATS' projects for collecting part of the material analysed in this study. We are grateful to Javier Sánchez Almazán (MNCN), Tatiana M. Steiner (ZUEC), and Aline Benetti (MZUSP) for providing museum numbers, and to Dr Angelika Brandt and the staff of the ZMH for all the support during a visit of one of us (MVF) to that collection. Finally, we would like to thank Thaís Pires Miranda, for helping us with the examination of specimens of E. rolani, and Prof. Guillermo San Martín, one anonymous referee, and the editor Dr. Nancy J. Maciolek, whose corrections and suggestions greatly improved the quality of this paper.

\section{References}

Abd-Elnaby, F.A. \& San Martin, G. (2010) Eusyllinae, Anoplosyllinae, and Exogoninae (Polychaeta: Syllidae) for the Mediterranean Coasts of Egypt, together the description of one new species. Life Science Journal, 7 (4), $132-139$.

Aguado, M.T. \& San Martín, G. (2007) Syllidae (Polychaeta) from Lebanon with two new reports for the Mediterranean Sea. Cahiers de Biologie Marine, 48, 207-224.

Aguado, M.T. \& San Martín, G. (2009) Phylogeny of the Syllidae (Polychaeta) based on morphological data. Zoologica Scripta $38,379-402$. http://dx.doi.org/10.1111/j.1463-6409.2008.00380.x

Aguado, M.T., Nygren, A. \& Siddall, M.E. (2007) Phylogeny of Syllidae (Polychaeta) based on combined molecular analysis of nuclear and mitochondrial genes. Cladistics, 23 (6), 552-564. http://dx.doi.org/10.1111/j.1096-0031.2007.00163.x

Aguado, M.T., San Martín, G. \& Siddall, M.E. (2011) Systematics and evolution of syllids (Annelida, Syllidae). Cladistics, 28 (3), 234-250.

Amaral, A.C.Z., Nallin, S.A.H., Steiner, T.M., Forroni, T.O. \& Gomes-Filho, D. (2012) Catálogo das espécies de Annelida Polychaeta do Brasil. Available from: http://www.ib.unicamp.br/projbiota/bentos_marinho/prod_cien/texto_poli.pdf. (acessed 1 June 2013)

Amaral, A.C.Z., Lana, P.C. Fernandes, F.C. \& Coimbra, J.C. (2004) Parte I - Caracterização do ambiente e da macrofauna bentônica. In: Amaral, A.C.Z. \& Rossi-Wongtschowski, C.L.B. (Eds.), Biodiversidade Bentônica da Região Sudeste-Sul 
do Brasil - Plataforma Externa e Talude Superior. (Série Documentos REVIZEE-Score Sul). Instituto Oceanográfico, São Paulo. pp. 11-46.

Berkeley, E. \& Berkeley, C. (1938) Notes on Polychaeta from the coast of western Canada. 2. Syllidae. Annals and Magazine of Natural History, 1, 33-49.

Berlandi, R.M., Figueiredo, M.A.O. \& Paiva, P.C. (2011) Rhodolith morphology and the diversity of polychaetes off the Southeastern Brazilian coast. Journal of Coastal Research, 28, 280-287. http://dx.doi.org/10.2112/11t-00002.1

Böggemann M. \& Westheide W. (2004) Interstitial Syllidae (Annelida: Polychaeta) from Mahé (Seychelles). Journal of Natural History, 38, 403-446. http://dx.doi.org/10.1080/0022293021000033229

Campoy, A. (1982) Fauna de España. Fauna de Anélidos Poliquetos de la Península Ibérica. Publicaciones de Biología de la Universidad de Navarra, Série Zoológica, 7 (1). EUNSA (Ediciones de la Universidad de Navarra), Pamplona, 781 pp.

Capa, M., San Martín, G. \& López, E. (2001) Autolytinae, Eusyllinae and Exogoninae (Syllidae: Polychaeta) from Coiba National Park, Panamá. Revista de Biologia Tropical, 49 (2), 621-627.

Claparède, E. (1864) Glanures zootomiques parmi les Annélides de Port-Vendres (Pyrenées Orientales). Mémoires de la Societé de Physique et d'Histoire Naturelle de Géneve, 17 (2), 463-600.

Claparède, E. (1868) Les annélides chétopodes du Golfe de Naples. Mémoires de la Société de physique et d'Histoire naturelle de Genève, 19, 313-584.

Day, J.H. (1967) A Monograph on the Polychaeta of Southern Africa, 1. Errantia. Brit Mus (Nat Hist) London Publ, (656), $1-458$.

Friedrich, H. (1956) Mitteilungen über neue und wenig bekannte Polychaeten aus Mittel- und Südamerika. Senckenbergiana biologica, 37, 57-68.

Fukuda, M.V. (2010) Contribuição ao conhecimento taxonômico dos silídeos (Polychaeta: Syllidae) da região sudeste-sul do Brasil. Ph. D. Thesis, Instituto de Biociências da Universidade de São Paulo, São Paulo, 340 pp.

Fukuda, M.V., Centurion, R., Nogueira, J.M.M. \& San Martin, G. (2012) Two new species of Paraehlersia San Martin, 2003 (Polychaeta, Syllidae) from the Atlantic Coast of South America. Zootaxa, 3264, 38-52.

Fukuda, M.V. \& Nogueira, J.M.M. (2006) A new species of Odontosyllis Claparède, 1863 (Polychaeta: Syllidae: Eusyllinae), and description of Brazilian material of Odontosyllis cf. fulgurans (Audouin and Milne Edwards, 1834). Zoological Studies, 45, 223-233.

Fukuda, M.V. \& Nogueira, J.M.M. (2013a) On a new species of Nuchalosyllis (Polychaeta: Syllidae), a rare syllid genus only known from Brazilian waters. Journal of the Marine Biological Association of the United Kingdom, 93, 963-966. http://dx.doi.org/10.1017/s0025315412000069

Fukuda, M.V. \& Nogueira, J.M.M. (2013b) First occurrence of Perkinsyllis San Martín, López \& Aguado, 2009 (Polychaeta: Syllidae) in Brazil, with descriptions of two new species. Marine Biology Research, 9, 972-989. http://dx.doi.org/10.1080/17451000.2013.793807

Fukuda, M.V., Nogueira, J.M.M., Paresque, K. \& San Martín, G. (2013) Species of Odontosyllis Claparède, 1863 (Annelida: Polychaeta: Syllidae) occurring along the Brazilian coast. Zootaxa, 3609 (2), 142-162. http://dx.doi.org/10.11646/zootaxa.3609.2.2

Fukuda, M.V., Yunda-Guarín, G. \& Nogueira, J.M.M. (2009) The genus Prosphaerosyllis (Polychaeta: Syllidae: Exogoninae) in Brazil, with description of a new species. Journal of the Marine Biological Association of the United Kingdom, 89, 1443-1454. http://dx.doi.org/10.1017/s0025315409000095

Gardiner, S.L. (1975) Errant polychaete annelids from North Carolina. Journal Elisha Mitchell Scient Soc, 91 (3), 77-220.

Grube, A.E. (1850) Die Familien der Anneliden. Archiv für Naturgeschichte 16, 249-364.

Hartmann-Schroder, G. (1959) Zur Okologie der Polychaeten des Mangrove-Estero-Gebietes von El Salvador. Beitraege zur Neotropischen Fauna, 1, 69-183. http://dx.doi.org/10.1080/01650525909380612

Hartmann-Schröder, G. (1960) Polychaeten aus dem Roten Meer. Kieler Meeresforschungen, 16, 69-125.

Hartmann-Schröder, G. (1974) Zur Kenntnis des Eulitorals der afrikanischen Westkuste zwischen Angola und Kap der Guten Hoffnung und der afrikanischen Ostkuste von Sudafrika und Mocambique unter besonderer Berücksichtigung der Polychaeten und Ostracoden. Teil 2. Die Polychaeten des Untersuchungsgebietes. Mitteilungen aus dem Hamburgischen Zoologischen Museum und Institut, , 68, 95-228.

Imajima, M. (1966) The Syllidae (polychaetous annelids) from Japan. I. Exogoninae. Publications of the Seto Marine Biological Laboratory, 13, 385-404.

Lana, P.C. (1984) Anelídeos poliquetas errantes do litoral do estado do Paraná. Tese de Doutorado - Instituto Oceanográfico, Universidade de São Paulo, 275 pp.

Langerhans, P. (1879) Die Wurmfauna von Madeira. Zeitschrift für wissenschaftliche Zoologie, 32, 513-592

Mesnil, F.Y \& Caullery, M. (1918) Sur l'organisation et la biologie d'un Syllidien Exogone (Parexogone n. s.g.) hebes Webster et Benedict, var. hibernica Southern, habitant un sable compacte. Bulletin de la Société Zoologique de France, 42, 126-132.

Morgado, E.H. \& Amaral, A.C.Z. (1985) Anelídeos poliquetos associados ao briozoário Schizoporella unicornis (Johnston). V. 
Syllidae. Revista Brasileira de Zoologia, 3, 219-227.

http://dx.doi.org/10.1590/s0101-81751985000400008

Nogueira, J.M.M. (2000) Anelídeos poliquetas associados ao coral Mussismilia híspida (Verril, 1868) em ilhas do litoral do Estado de São Paulo. Phyllodocida, Amphinomida, Eunicida, Spionida, Terebellida, Sabellida. Tese de Doutorado Instituto de Biociências, Universidade de São Paulo, 265 pp.

Nogueira, J.M.M. (2006) Família Syllidae. In: Amaral, A.C.Z., Rizzo, A.E., Arruda, E.P., (Eds.), Manual de Identificação dos Invertebrados Marinhos da Região Sudeste-Sul do Brasil. São Paulo, SP: Editora da Universidade de São Paulo, 134-164.

Nogueira, J.M.M. \& Fukuda, M.V. (2008) A new species of Trypanosyllis Claparède, 1864 (Polychaeta: Syllidae) from Brazil, with a redescription of Brazilian material of Trypanosyllis zebra. Journal of the Marine Biological Association of the United Kingdom, 88 (5), 913-924.

http://dx.doi.org/10.1017/s0025315408001707

Nogueira, J.M.M. \& San Martín, G. (2002) Species of Syllis Savigny in Lamarck, 1818 (Polychaeta: Syllidae) living in corals in the state of São Paulo, southeastern Brazil. Beaufortia, 52, 57-93.

Nogueira, J.M.M. \& Yunda-Guarín, G. (2008) A new species of Syllis (Polychaeta: Syllidae: Syllinae) from off Fortaleza, north-eastern Brazil. Journal of the Marine Biological Association of the United Kingdom, 88, 1391-1399. http://dx.doi.org/10.1017/s0025315408002099

Nogueira, J.M.M., San Martín, G. \& Amaral, A.C.Z. (2001) Description of five new species of Exogoninae (Polychaeta, Syllidae) associated with the stony coral Mussismilia hispida (Verrill, 1868) in São Paulo State, Brazil. Journal of Natural History, 35, 1773-1794. http://dx.doi.org/10.1080/00222930152667096

Nogueira, J.M.M., San Martín, G. \& Fukuda, M.V. (2004) On some exogonines (Polychaeta, Syllidae) from the northern coast of the State of São Paulo, southeastern Brazil - Results of BIOTA/FAPESP/BentosMarinho Project. Meiofauna Marina, $13,45-78$.

Núñez, J., San Martín, G. \& Brito, M.C. (1992) Exogoninae (Polychaeta, Syllidae) from the Canary Islands. Scientia Marina, $56(1), 43-52$.

Nygren, A. \& Gidholm, L. (2001) Three new species of Proceraea (Polychaeta: Syllidae: Autolytinae) from Brazil and the United States, with a synopsis of all Proceraea-like taxa. Ophelia, 54, 177-191. http://dx.doi.org/10.1080/00785236.2001.10409464

Ørsted, A.E. (1845) Ueber die Entwicklung der Jungen bei einer Annelide und über änveren Untersuchiede zwischen beiden Geschlechtern. Archiv für Naturgeschichte Berlin, 11, 20-23.

Paiva, P.C., Young, P.S. \& Echeverría, C.A. (2007) The Rocas Atoll, Brazil: a preliminary survey of the crustacea and polychaete fauna. Arquivos do Museu Nacional, Rio de Janeiro, 65, 241-250.

Paresque, K. \& Nogueira, J.M.M. (2014) The genus Haplosyllis Langerhans, 1879 (Polychaeta: Syllidae) from off northeastern Brazil, with descriptions of two new species. Marine Biology Research, 6, 554-576. http://dx.doi.org/10.1080/17451000.2013.841941

Paresque, K. (2008) Influência das características do hábitat na comunidade macrobentônica associada a diferentes fitais no entremarés da Ilha do Boi, Vitória, Espírito Santo. Dissertação de Mestrado, Universidade Federal do Espírito Santo, 47 pp.

Pascual, M., Núñez, J. \& San Martín, G. (1996) Exogone (Polychaeta: Syllidae: Exogoninae) endobiontics of sponges from the Canary and Madeira Islands with description of two new species. Ophelia, 45 (1), 67-80. http://dx.doi.org/10.1080/00785326.1996.10432463

Perkins, T.H. (1981) Syllidae (Polychaeta), principally from Florida, with descriptions of a new genus and twenty-one new species. Proceedings of the Biological Society of Washington, 93, 1080-1172.

Ruiz-Ramírez, J.D. \& Salazar-Vallejo, S. (2001) Exogoninae (Polychaeta: Syllidae) from the Mexican Caribbean with a key to the Great Caribbean species. Revista de Biología Tropical, 49 (1), 117-140.

Rullier, F. \& Amoureux, L. (1979) Annélides Polychàetes. Annales de l'Institute Oceanographique, 55, $145-206$.

Russell, D.E. (1991) Exogoninae (Polychaeta: Syllidae) from the Belizean barrier reef with a key to species of Sphaerosyllis. Journal of Natural History, 25, 49-74. http://dx.doi.org/10.1080/00222939100770061

San Martín, G. (1984) Estudio biogeográfico, faunístico y sistemático de los Poliquetos de la família Sílidos (Syllidae: Polychaeta) en Baleares. Publicaciones de la Universidad Complutense de Madrid, 187, 1-581.

San Martín, G. (1991) Grubeosyllis and Exogone (Exogoninae, Syllidae, Polychaeta) from Cuba, the Gulf of Mexico, Florida and Puerto Rico, with a revision of Exogone. Bulletin of Marine Science, 49, 715-740.

San Martín, G. (2003) Annelida Polychaeta II: Syllidae. In: Ramos, M.A. et al. (Eds.), Fauna Ibérica. Vol. 21. Museo Nacional de Ciências Naturales, CSIC, Madrid, pp. 1-544.

San Martín, G. (2005) Exogoninae (Polychaeta, Syllidae) from Australia with the description of a new genus and twenty-two new species. Records of the Australian Museum, 57, 39-152. http://dx.doi.org/10.3853/j.0067-1975.57.2005.1438

San Martín, G. \& Bone, D. (2001) Syllidae (Polychaeta) de praderas de Thalassia testudinum en el Parque Nacional Morrocoy (Venezuela). Revista de Biología Tropical, 49, 609-620.

San Martín, G. \& Hutchings, P. (2006) Eusyllinae (Polychaeta: Syllidae) from Australia with the description of a new genus and 
fifteen new species. Records of the Australian Museum, 58, 257-370.

http://dx.doi.org/10.3853/j.0067-1975.58.2006.1466

San Martín, G., Hutchings, P. \& Aguado, M.T. (2008a) Syllinae (Polychaeta, Syllidae) from Australia. Part. 2. Genera Inermosyllis, Megasyllis n. gen., Opisthosyllis, and Trypanosyllis. Zootaxa, 1840, 1-53.

San Martín, G., Hutchings, P. \& Aguado, M.T. (2008b) Syllinae (Polychaeta, Syllidae) from Australia. Part 1. Genera Branchiosyllis, Eurysyllis, Karroonsyllis, Parasphaerosyllis, Plakosyllis, Rhopalosyllis, Tetrapalpia n. gen., and Xenosyllis. Records of the Australian Museum, 60, 19-160. http://dx.doi.org/10.3853/j.0067-1975.60.2008.1494

San Martín, G., Hutchings, P. \& Aguado, M.T. (2010) Syllinae (Polychaeta: Syllidae) from Australia. Part 3. Genera Alcyonosyllis, Parahaplosyllis, and Trypanosyllis (Trypanobia). Zootaxa, 2493, 35-48.

San Martín, G. \& López, E. (2003) A new genus of Syllidae (Polychaeta) from Western Australia. Hydrobiologia, 496, 191-197. http://dx.doi.org/10.1023/a:1026140714187

Sovierzoski, H.H. (1999) Anelídeos poliquetas do litoral de Alagoas, Brasil. Tese de Doutorado - Instituto de Biociências, Universidade de São Paulo, 208 pp.

Temperini, M.T. (1981) Sistemática e distribuição dos poliquetos errantes da plataforma continental brasileira entre as latitudes $23^{\circ} 05^{\prime}$ S e 3000S. Dissertação de Mestrado - Instituto Oceanográfico, Universidade de São Paulo. 89 pp.

Uebelacker, J.M. (1984) Family Syllidae Grube, 1850. In: Uebelacker, J.M. \& Johnson, P.G. (Eds.), Taxonomic Guide to the Polychaetes of the Northern Gulf of Mexico. Volume IV. Barry A. Vittor \& Associates, Metairie. pp. 30-151.

Webster, H.E. (1879) On the Annelida Chaetopoda of the Virginian coast. Transactions Albany Institute, 9, $202-272$.

Westheide, W. (1974) Interstitielle Fauna von Galapagos. XI. Pisionidae, Hesionidae, Pilargidae, Syllidae (Polychaeta). Mikrofauna des Meersbodens, 44, 195-338.

Zottoli, R. \& Long, C.D. (2000) Exogone breviantennata Hartmann-Schroder, 1959 (characters emended) (Annelida: Polychaeta: Syllidae), a new record for the Bahamas with a key to selected Exogone species. Proceedings of the Biological Society of Washington, 113 (2), 500-513. 